23. Bernier I, Dautigny A, Glatthaar BE, Lergier W, Jolles J, Gillessen D, Jolles P (1980) Alpha-1-microglobulin from normal and pathological urines. Biochim Biophys Acta 626: 188-196

24. Topping MD, Forster HW, Dolman C, Luczynaka CM, Bernard AM (1986) Measurement of urinary retinol binding protein by enzymelinked immunosorbent assay, and its application to the detection of tubular proteinuria. Clin chem 32: 1863-1866
25. Walton C, Bodansky HJ, Wales JK, Forbes MA, Cooper EH (1988) Tubular dysfunction and microalbuminuria in insulin dependent diabetes. Arch Dis Child 63: 244-249

26. Sandberg T, Cooper EH, Lidin-Janson G, Yu H (1985) Fever and proximal tubular function in acute pyelonephritis. Nephron 41 : $39-44$

\section{Ask the expert*}

What treatment would you advise for a 1-year-old child with chronic renal failure who has been on aluminum hydroxide as a phosphate binder for 6 months and then develops epilepsy and is found to have a grossly raised plasma aluminum concentration?

Key word: Aluminium encephalopathy

The immediate approach advises discontinuation of aluminum hydroxide as a phosphate-binding agent and other pharmacological agents containing aluminum (Al), such as Sicralfate or Kaopectate. On a statistical basis, this young child is likely to have obstructive uropathy with renal dysplasia and renal bicarbonate wasting, and probably should be treated with Shol's solution. The most likely diagnosis in this child is that gastrointestinal absorption of A1 has resulted in encephalopathy and probably, as well in microcytic anemia and vitamin D-resistant osteomalacia [1], Severe Al intoxication may develop when Al-containing binders and buffered citrate solutions are ingested together, since citrate markedly enhances the intestinal absorption [2].

In some children who have sufficient residual renal function that permits $\mathrm{Al}$ excretion, intoxication can resolve after administration of Al-containing binders is stopped. As described, this child already has convulsions, which presumably are not due to uremia or another metabolic disorder, but rather to Al-induced encephalopathy. Thus, therapy with deferoxamine (DFO) is indicated.

$\mathrm{DFO}$ is effective in treating $\mathrm{Al}$ intoxication in non-dialyzed patients with chronic renal failure (CRF) and in patients undergoing all forms of dialysis. Because $\mathrm{Al}$ is tightly bound to proteins, essentially none is removed by dialysis in the absence of a chelating agent such as DFO. DFO forms a freely diffusable chelate which can be given by the intravenous, intramuscular, or intraperitoneal route. Long-term therapy with DFO should be reserved for those patients with well-documented evidence of $\mathrm{Al}$ toxicity, including bone disease and neurological involvement $[3,4]$. DFO can cause lens abnormalities, leukopenia, cardiac arrhythmias and allergic reactions. It recently has been associated with fatal infections involving Yersinia and Rhizopus (a fungus, [5]). Thus, DFO should be administered cautiously at a dosage of $10-20 \mathrm{mg} / \mathrm{kg}$ once a week; plasma $\mathrm{Al}$ levels should be monitored after DFO therapy is begun. Plasma Al levels should not exceed $800-1000 \mu \mathrm{g} / \mathrm{l}$, because greater values may exacerbate the encephalopathy. The duration of DFO therapy is difficult to estimate. However, because of its toxicity, DFO should be discontinued as soon as maximal clinical improvement is noted.

* The editors invite questions for this section
Al-induced encephalopathy, osteomalacia and microcytic anemia are iatrogenic diseases; hence, they are preventable. Because the main cause of $\mathrm{Al}$ intoxication in a child with $\mathrm{CRF}$ is the gastrointestinal absorption of $\mathrm{Al}, \mathrm{Al}$-containing antacids should not be given. Infant diet can be regulated adequately by using a low phosphate formula with the addition of calcium carbonate as needed [6]. If small amounts of $\mathrm{Al}$ are needed to control serum phosphate concentrations, calcium citrate should be avoided as this enhances the intestinal absorption of $\mathrm{Al}$.
Sharon P. Andreoli

Indiana University

Riley Children's Hospital

Indianapolis, Indiana, USA

Isidro B. Salusky

University of California,

Los Angeles

Los Angeles, California, USA

\author{
Russell W. Chesney \\ The University of Tennessee, \\ Memphis \\ Le Bonheur Children's \\ Medical Center \\ Memphis, Tennessee, USA
}

Aileen B. Sedman

University of Michigan

A. Alfred Taubman H. C. C.

Ann Arbor, Michigan, USA

\section{References}

1. Andreoli SP, Bergstein JM, Sherrard DJ (1984) Aluminum intoxication from aluminum-containing phosphate binders in children with azotemia not undergoing dialysis. N Engl J Med 310: 1079- 1082

2. Slanina P, Frech W, Ekstrom LG, Loof L, Slorach S, Cedergren A (1985) Dietary citric acid enhances absorption of aluminum in antacids. Clin Chem 32: 539-541

3. Windus DW, Stokes TJ, Julian BA, Feuves AZ (1987) Fatal rhizopus infections in hemodialysis patients receiving deferoxamine. Ann Intern Med 107: 678-680

4. Warady BA, Ford DM, Gaston CE, Sedman AB, Huffer WE, Lum GM (1986) Aluminum intoxication in a child: treatment with intraperitoneal desferrioxamine. Pediatrics 78: 651-655

5. Andreoli SP, Dunn D, DeMeyer W, Sherrard DJ, Bergstein JM (1985) Intraperitoneal deferoxamine therapy for aluminum intoxication in a child undergoing continuous ambulatory peritoneal dialysis. J Pediatr 107: 760-763

6. Salusky IB, Coburn JW, Foley J, Nelson P, Fine RN (1986) Effects of oral calcium carbonate on control of serum phosphorus and changes in plasma aluminum levels after discontinuation of aluminum-containing gels in children receiving dialysis. J Pediatr 108: 767-770 